\title{
CHKA wt Allele
}

National Cancer Institute

\section{Source}

National Cancer Institute. CHKA wt Allele. NCI Thesaurus. Code C51051.

Human CHKA wild-type allele is located in the vicinity of 11 q13.2 and is approximately 69 $\mathrm{kb}$ in length. This allele, which encodes choline kinase alpha protein, plays a role in the initiation and regulation of phosphatidylcholine biosynthesis. The CHKA gene is overexpressed in several types of cancer such as breast, colon, lung and prostate cancers. 